\title{
COPPER ELECTROWINNING BASED ON REACTIVE ELECTRODIALYSIS
}

\author{
GERARDO CIFUENTES (1), JAIME SIMPSON (1), FRANCISCO LOBOS (1), LEONCIO BRIONES (2) AND \\ ALEJANDRO MORALES (3).
}

\author{
(1) Departamento de Ingeniería Metalúrgica, Facultad de Ingeniería, Universidad de Santiago de Chile, Avenida Libertador Bernardo O’Higgins 3363, \\ Casilla 10233, Fono: 56-2-7183224, Santiago, Chile. \\ (2) Departamento de Ingeniería Mecánica, Facultad de Ingeniería, Universidad de Santiago de Chile. \\ (3) Departamento de Ingeniería Metalúrgica, Universidad Católica del Norte. Avenida Angamos 0610, Antofagasta, Chile
}

(Received: July 22, 2008 - Accepted: May 20, 2009)

\begin{abstract}
This paper shows an alternative to the classic electrowinning copper process using a cell based on reactive electrodialysis, which consists of two compartments separated by an anionic membrane, one of which contains the copper sulphate catholyte, where the cathode is located, and the other compartment contains the ferrous sulfate anolyte, where the anode is located. In this type of cell the anodic reaction is the oxidation of iron $\left(\mathrm{Fe}^{2+}\right.$ to $\left.\mathrm{Fe}^{3+}\right)$, which consumes less energy than the classic water oxidation. Moreover, this new anodic reaction does not produce acid mist.
\end{abstract}

Keywords: Copper, electrowinning, electrodialysis.

\section{INTRODUCTION}

The conventional copper electrowinning process, in spite of its present extensive use, has some drawbacks that over the last 20 years have been attemped to be overcome ${ }^{1}$, but there are few implementations at the industrial level. These deficiencies are related mainly to the low electrolyte flow, whose direct consequence is a low efficiency of the mass transport phenomena. Furthermore, the specific surface area of the electrodes is low, and therefore the amount of mass deposited by chemical reaction is also low, and finally, among the drawbacks, there is a high energy requirement ${ }^{2}$ (see Table 1.1) because the dominant reaction is the anodic decomposition of water, whose standard potential referred to the normal hydrogen electrode (NHE) is $\mathrm{E}^{\mathbf{o}}=$ $1.23 \mathrm{~V}$. As a direct consequence of this reaction, acid mist is also produced by the action of the generated oxygen which drags electrolyte along its path. To prevent all these phenomena that occur during conventional electrowinning, anodic reactions other than that of water have been proposed, such as, for example: $\mathrm{Co} / \mathrm{Co}^{+3}\left(\mathrm{E}^{\mathrm{o}}=0.42 \mathrm{~V}_{\mathrm{NHE}}\right), \mathrm{I} / \mathrm{I}^{-}\left(\mathrm{E}^{\mathrm{o}}=0.54 \mathrm{~V}_{\mathrm{NHE}}\right), \mathrm{Ag} / \mathrm{Ag}^{+}\left(\mathrm{E}^{\mathrm{o}}=0.80\right.$ $\left.\mathrm{V}_{\mathrm{NHE}}\right), \mathrm{Pb} / \mathrm{Pb}^{+4}\left(\mathrm{E}^{\mathrm{o}}=0.77 \mathrm{~V}_{\mathrm{NHE}}\right), \mathrm{Hg} / \mathrm{Hg}^{+2}\left(\mathrm{E}^{\mathrm{o}}=0.85 \mathrm{~V}_{\mathrm{NHE}}\right)$, and the $\mathrm{Fe}^{+2} / \mathrm{Fe}^{+3}\left(\mathrm{E}^{\mathrm{o}}=\right.$ $\left.0.77 \mathrm{~V}_{\mathrm{NHE}}\right)$, and $\mathrm{Hg}_{2}{ }^{+2} / \mathrm{Hg}^{+2}\left(\mathrm{E}^{\mathrm{o}}=0.92 \mathrm{~V}_{\mathrm{NHE}}\right)$ redox couples. ${ }^{3,4}$ Any of the above reactions can decrease the total energy of the copper electrowinning cell if the following basic conditions are fulfilled: that the algebraic sum of their Nernst equilibrium potentials ( $\left.\mathrm{E}_{\text {cathode }}-\mathrm{E}_{\text {anode }}=\Delta \mathrm{E}_{\mathrm{eq}}\right)$ and the anodic overpotential are less than those that consider the evolution of oxygen from the oxidation of water, thereby having as a direct consequence a low cost due to energy savings and less impact on the work areas due to the elimination of acid mist. ${ }^{5}$ One of the most promising reactions is the transformation of ferrous to ferric ion mentioned above. ${ }^{6,7}$ One way of preventing the reverse reaction (from ferric to ferrous) from taking place at the cathode and thereby affecting the faradic cathodic efficiency, consists in using two electrolytes (anolyte and catholyte) instead of only one, retaining the conductivity between them. ${ }^{8,9,10,11,12}$ This is possible using an electrodialysis membrane to separate those electrolytes in order to obtain specific electrode reactions. This process is known as reactive electrodialysis (RED). In this context it must also be considered that the sum of the resistances of the catholyte, the anolyte, and the membrane is not greater than the decrease achieved by changing the anodic reaction as well as by decreasing the corresponding overpotential. ${ }^{13}$

Table 1.1.- Distribution of potential in conventional electrowinning

\begin{tabular}{|l|c|c|}
\hline \multicolumn{1}{|c|}{ Parameter } & Volts & $\%$ \\
\hline$\Delta E_{e q}=$ Equilibrium potential dif. & 0.9 & 42.8 \\
\hline$\left|\eta_{a}\right|=$ Anodic overpotential & 0.5 & 23.8 \\
\hline$\eta_{c}=$ Cathodic overpotential & 0.05 & 2.4 \\
\hline$I \cdot R_{e}$ drop in the electrolyte at $200 \mathrm{~A} / \mathrm{m}^{2}$ & 0.5 & 23.8 \\
\hline Loss from contact & 0.15 & 7.2 \\
\hline$V_{\text {cell }}=$ Total cell voltage & 2.1 & 100.0 \\
\hline
\end{tabular}

Table 1.1 can be represented in mathematical terms, with the potential difference that is produced in the conventional electrowinning cell expressed by

$$
V_{\text {cell }}=E+I \cdot R_{e}
$$

where. $E=\Delta E_{e}+\eta_{a}+\left|\eta_{c}\right|$ This differs with respect to the cell potential expression associated with a reactive electrodialysis process that considers the following terms:

$$
V_{\text {cell }}=\Delta E_{e q}+\eta_{a}+\left|\eta_{c}\right|+I \cdot\left(R_{a}+R_{c}+R_{m}\right)
$$

where $R_{a}, R_{c}$ and $R_{m}$ are the resistances associated with the anolyte, catholyte, and membrane, respectively. The above expressions do not consider losses associated with electronic contacts and/or conductors.

On the other hand, the specific energy consumption $(W)$ for any copper electrolysis cell is given by:

$$
W=\frac{V_{\text {cell }} \cdot I \cdot t}{M_{\text {deposited copper }}}
$$

where $I$ is the current fed and $t$ is electrolysis time, usually in amperes and hours, respectively. $M$ is the copper deposited on the cathode.

Most industrial electrolytic processes in the copper speciality work under mass transfer control. If diffusion, $J_{p}$, is the transport mechanism, the flux equality condition becomes:

$$
\frac{i}{n \cdot F}=J_{D}
$$

where $i$ is the current density, $n$ is the electrons transferred, and $F$ is Faraday's constant. Thus, using Fick's law of diffusion, one has:

$$
\frac{i}{n \cdot F}=J_{D}=-D \cdot\left(\frac{d c}{d x}\right)_{x=0}
$$

In general, this concentration profile is such that there is a linear variation of concentration over small distances from the interface and then the concentration asymptotically approaches the bulk value $c^{0}$. Nernst put forward a simplifying suggestion, extrapolating the linear part of the concentrationversus-distance curve until it intersects the bulk value of the concentration at some distance $\delta$ from the interface. Then, the concentration gradient at $\mathrm{x}=0$, i.e. $(\mathrm{dc} / \mathrm{dx}) \mathrm{x}=0$, can be replaced by $\left(c 0-c_{\mathrm{x}=0}\right) / \delta$ to give: 


$$
\frac{i}{n \cdot F}=J_{D}=-D \cdot\left(\frac{c^{0}-c_{x=0}}{\delta}\right)
$$

where $c_{x=0}$ is the concentration at the electrode interface.

Therefore, each overpotential present in equations (1) and (2) can be written separately as:

$$
\eta=\eta_{T C}+\eta_{D}
$$

here $\eta_{T C}$ and $\eta_{D}$ are the transport charge and diffusional overpotential, respectively.

In this approximation, therefore, one can consider that the diffusion occurs across a region parallel to the electrode interface, i.e., across a Nernst diffusion layer of effective thickness $\delta$. The precise value of the above diffusion layer depends largely on the effectiveness of forced convection, and is smaller the grater the effectiveness is. Generally, convection is laminar where the value of $\delta$ and hence of the concentration gradient is governed by the electrode geometry, the kinematic viscosity, the diffusion coefficient, and the velocity of the liquid caused by stirring; turbulent flow is also usually involved when the electrolyte is stirred. Both types of convection have been described by Levich ${ }^{1}$.

There are studies related to the process of electrodialysis associated with copper, but they are still confusing and contradictory. ${ }^{14,15,16,17}$ An important aspect is that related to operational flow, which causes great expectation because if work can be done with greater flows, higher limiting currents would be obtained as a consequence of higher current density, leading to the same copper production with a much smaller infrastructure. ${ }^{18,19}$ Reactive electrodialysis applied to the electrowinning of copper is a vision of the future in the present.

This paper attempts to demonstrate that copper electrowinning based on reactive electrodialysis can be a good alternative process compared to the present electrowinning process in terms of specific energy, cell voltage, and current density.

\section{EXPERIMENTAL PART}

Figure 2.1 presents the experimental scheme used in this work.

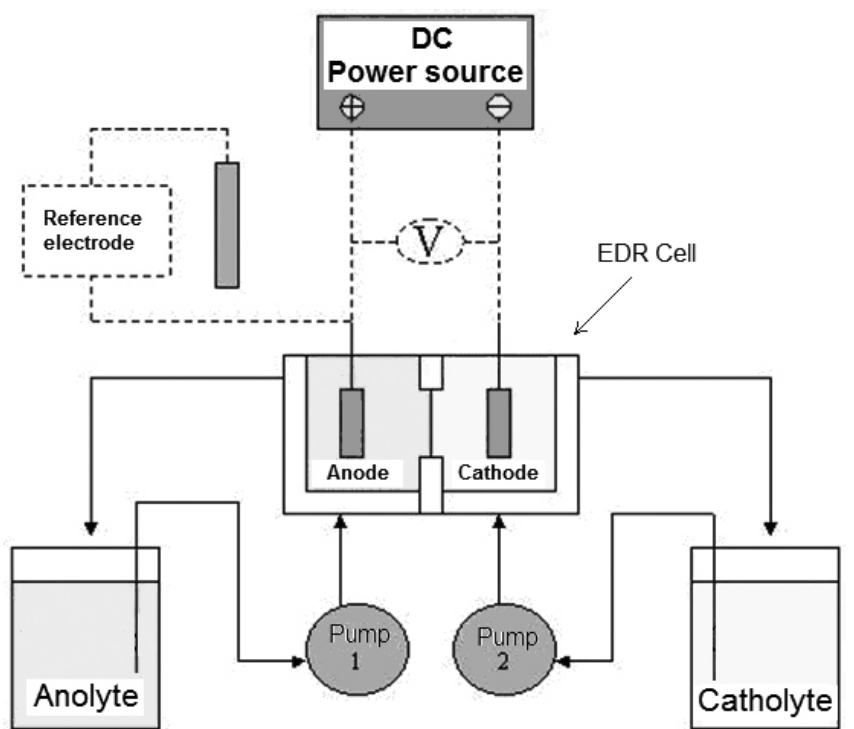

Figure 2.1: Experimental scheme of RED used in this study.

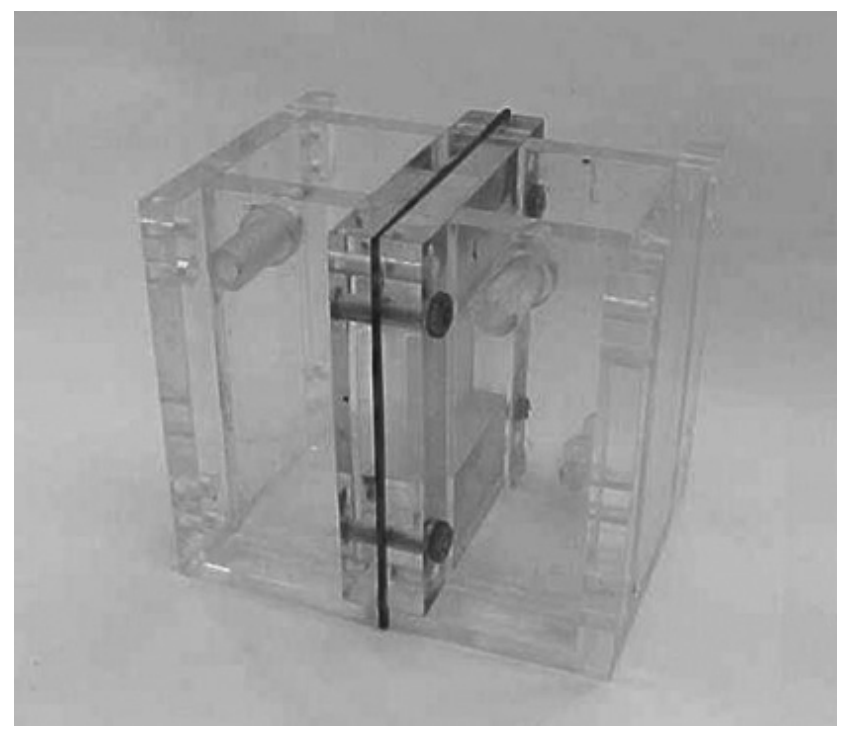

Figure 2.2: Electrodialysis cell used in this study. used in this study.

The effective catholyte and anolyte volumes in the compartment were 275 $\mathrm{cm}^{3}$ of each, adding up to a total volume of $550 \mathrm{~cm}^{3}$, because both electrolytes were recirculated with peristaltic pumps at flows of 700, 800, 900 and 1,200 $\mathrm{cm}^{3} / \mathrm{min}$. The electrolyte's working temperatures were 40,50 and $60{ }^{\circ} \mathrm{C}$.

The cathode consisted of a $4 \mathrm{~cm}^{2}$ copper sheet and the anode was made of platinum, with their back sides insulated with teflon. The cathode current densities used were 300,450 and $600 \mathrm{~A} / \mathrm{m}^{2}$. A $2 \times 2 \mathrm{~cm}$ Ionac MA3475 anionic membrane was used as the separation medium between the two electrolyte compartments. This membrane was attached to the separating frame by means of rubber gaskets, as shown in Figure 2.2. The composition of the anolyte was $190 \mathrm{~g} / \mathrm{L}$ of $\mathrm{H}_{2} \mathrm{SO}_{4}$ and a $1 \mathrm{M}$ concentration of $\mathrm{Fe}^{2+}\left(\mathrm{as} \mathrm{FeSO}_{4} \cdot 7 \mathrm{H}_{2} \mathrm{O}\right)$. The composition of the catholyte was $190 \mathrm{~g} / \mathrm{L}$ of $\mathrm{H}_{2} \mathrm{SO}_{4}$ and $30 \mathrm{~g} / \mathrm{L}$ of $\mathrm{Cu}^{2+}$ as $\mathrm{CuSO}_{4} \cdot 5 \mathrm{H}_{2} \mathrm{O}$ ).

Electrolysis time for all the tests was 2 hours.

\section{RESULTS AND DISCUSSION}

The results are presented in the following tables and graphics.

Table 3.1.- Experimental results of tests at an electrolyte flow of $700 \mathrm{~cm}^{3 /}$ $\min$.

\begin{tabular}{|c|c|c|c|c|c|}
\hline $\begin{array}{c}\text { Temperature } \\
{ }^{\circ} \mathrm{C}\end{array}$ & Test No. & $\begin{array}{c}\text { Current } \\
\text { density } \\
\left(\mathrm{A} / \mathrm{m}^{2}\right)\end{array}$ & $\begin{array}{c}\mathrm{V}_{\text {cell }} \\
(\mathrm{V})\end{array}$ & $\begin{array}{c}\text { Deposited } \\
\text { copper } \\
(\mathrm{g})\end{array}$ & $\begin{array}{c}\text { Specific } \\
\text { Energy } \\
(\mathrm{kWh} / \mathrm{kg} \mathrm{Cu})\end{array}$ \\
\hline & 1 & 300 & 1.9 & 0.2822 & 1.62 \\
\hline 40 & 2 & 450 & 2.1 & 0.4199 & 1.80 \\
\hline & 3 & 600 & 2.3 & 0.5604 & 1.97 \\
\hline & 4 & 300 & 0.7 & 0.2796 & 0.60 \\
\hline 50 & 5 & 450 & 1.1 & 0.4233 & 0.94 \\
\hline & 6 & 600 & 2.2 & 0.5594 & 1.89 \\
\hline & & & & & \\
\hline & 7 & 300 & 0.7 & 0.2821 & 0.60 \\
\hline 60 & 8 & 450 & 1.08 & 0.4192 & 0.93 \\
\hline & 9 & 600 & 1.3 & 0.5593 & 1.12 \\
\hline
\end{tabular}


Table 3.2.- Experimental results of tests at an electrolyte flow of $800 \mathrm{~cm}^{3} /$ $\min$.

\begin{tabular}{|c|c|c|c|c|c|}
\hline $\begin{array}{c}\text { Temperature } \\
{ }^{\circ} \mathrm{C}\end{array}$ & $\begin{array}{c}\text { Test } \\
\text { No. }\end{array}$ & $\begin{array}{c}\text { Current } \\
\text { density } \\
\left(\mathrm{A} / \mathrm{m}^{2}\right)\end{array}$ & $\begin{array}{c}\mathrm{V}_{\text {cell }} \\
(\mathrm{V})\end{array}$ & $\begin{array}{c}\text { Deposited } \\
\text { copper } \\
(\mathrm{g})\end{array}$ & $\begin{array}{c}\text { Specific } \\
\text { Energy } \\
(\mathrm{kWh} / \mathrm{kg} \mathrm{Cu})\end{array}$ \\
\hline & 10 & 300 & 1.2 & 0.2812 & 1.02 \\
\hline 40 & 11 & 450 & 1.45 & 0.4209 & 1.24 \\
\hline & 12 & 600 & 2.3 & 0.5608 & 1.97 \\
\hline & & & & & \\
\hline & 13 & 300 & 0.7 & 0.2821 & 0.60 \\
\hline 50 & 14 & 450 & 1.07 & 0.4195 & 0.92 \\
\hline & 15 & 600 & 2.4 & 0.5606 & 2.05 \\
\hline & & & & & \\
\hline 60 & 16 & 300 & 0.65 & 0.2809 & 0.56 \\
\hline & 17 & 450 & 1 & 0.4209 & 0.86 \\
\hline & 18 & 600 & 1.3 & 0.5596 & 1.12 \\
\hline
\end{tabular}

Table 3.3.- Experimental results of tests at an electrolyte flow of $900 \mathrm{~cm}^{3 /}$ min.

\begin{tabular}{|c|c|c|c|c|c|}
\hline $\begin{array}{c}\text { Temperature } \\
{ }^{\circ} \mathrm{C}\end{array}$ & Test No. & $\begin{array}{c}\text { Current } \\
\text { density } \\
\left(\mathrm{A} / \mathrm{m}^{2}\right)\end{array}$ & $\begin{array}{c}\mathrm{V}_{\text {cell }} \\
(\mathrm{V})\end{array}$ & $\begin{array}{c}\text { Deposited } \\
\text { copper } \\
(\mathrm{g})\end{array}$ & $\begin{array}{c}\text { Specific } \\
\text { Energy } \\
(\mathrm{kWh} / \mathrm{kg} \mathrm{Cu})\end{array}$ \\
\hline & 19 & 300 & 0.9 & 0.2819 & 0.77 \\
\hline 40 & 20 & 450 & 1.3 & 0.4205 & 1.11 \\
\hline & 21 & 600 & 2.4 & 0.5595 & 2.06 \\
\hline & & & & & \\
\hline & 22 & 300 & 0.7 & 0.2806 & 0.60 \\
\hline 50 & 23 & 450 & 1.1 & 0.4190 & 0.95 \\
\hline & 24 & 600 & 2.2 & 0.5601 & 1.89 \\
\hline & & & & & \\
\hline & 25 & 300 & 0.62 & 0.2813 & 0.53 \\
\hline 60 & 26 & 450 & 0.9 & 0.4201 & 0.77 \\
\hline & 27 & 600 & 1.2 & 0.5613 & 1.03 \\
\hline
\end{tabular}

Table 3.4.- Experimental results of tests at an electrolyte flow of 1,200 $\mathrm{cm}^{3} / \mathrm{min}$.

\begin{tabular}{|l|l|l|l|l|l|}
\hline $\begin{array}{c}\text { Temperature } \\
{ }^{\circ} \mathrm{C}\end{array}$ & Test No. & $\begin{array}{c}\text { Current } \\
\text { density } \\
\left(\mathrm{A} / \mathrm{m}^{2}\right)\end{array}$ & $\begin{array}{c}\mathrm{V}_{\text {cell }} \\
(\mathrm{V})\end{array}$ & $\begin{array}{c}\text { Deposited } \\
\text { copper } \\
(\mathrm{g})\end{array}$ & $\begin{array}{c}\text { Specific } \\
\text { Energy } \\
(\mathrm{kWh} / \mathrm{kg} \mathrm{Cu})\end{array}$ \\
\hline & 28 & 300 & 0.8 & 0.2829 & 0.68 \\
\hline 40 & 29 & 450 & 1.12 & 0.4215 & 0.96 \\
\hline & 30 & 600 & 2.4 & 0.5607 & 2.05 \\
\hline & & & & & \\
\hline & 31 & 300 & 0.7 & 0.2810 & 0.60 \\
\hline 50 & 32 & 450 & 0.9 & 0.4214 & 0.77 \\
\hline & 33 & 600 & 2.2 & 0.5631 & 1.88 \\
\hline & & & & & \\
\hline & 34 & 300 & 0.6 & 0.2826 & 0.51 \\
\hline 60 & 35 & 450 & 0.8 & 0.4210 & 0.68 \\
\hline & 36 & 600 & 1.1 & 0.5618 & 0.94 \\
\hline
\end{tabular}

Effect of electrolyte flow:

From all the results, except at $600 \mathrm{~A} / \mathrm{m}^{2}$, it is seen that as electrolyte flow in the cell increases, there is a decrease of the corresponding potential difference. This can be explained graphically with an Evans diagram, shown in Figure 3.1, where for a fixed current density, for example, cell potential decreases as electrolyte flow $\left(Q_{i}\right)$ in the cell increases.

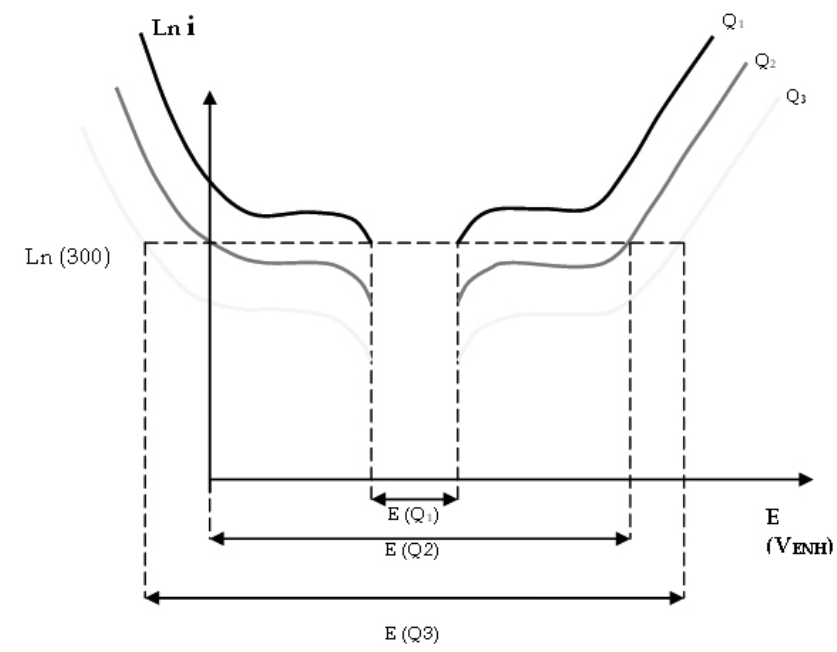

Figure 3.1.- Explanatory Evans diagram for different electrolytes flows $\left(Q_{i}\right)$ at the same current density of $300 \mathrm{~A} / \mathrm{m}^{2}$, where: $\left.\left.\left(Q_{1}\right\rangle Q_{2}\right\rangle Q_{3}\right)$.

In fact, if we work at a constant temperature of $40{ }^{\circ} \mathrm{C}$ and a current density of $300 \mathrm{~A} / \mathrm{m}^{2}$, see Figure 3.2, we get a cell potential of $1.9 \mathrm{~V}$ for $700 \mathrm{~cm}^{3} / \mathrm{min}$, $1.2 \mathrm{~V}$ for $800 \mathrm{~cm}^{3} / \mathrm{min}, 0.9 \mathrm{~V}$ for $900 \mathrm{~cm}^{3} / \mathrm{min}$, and $0.8 \mathrm{~V}$ for $1,200 \mathrm{~cm}^{3} / \mathrm{min}$, all of them lower than the conventional cell potentials shown in Table 1.1.

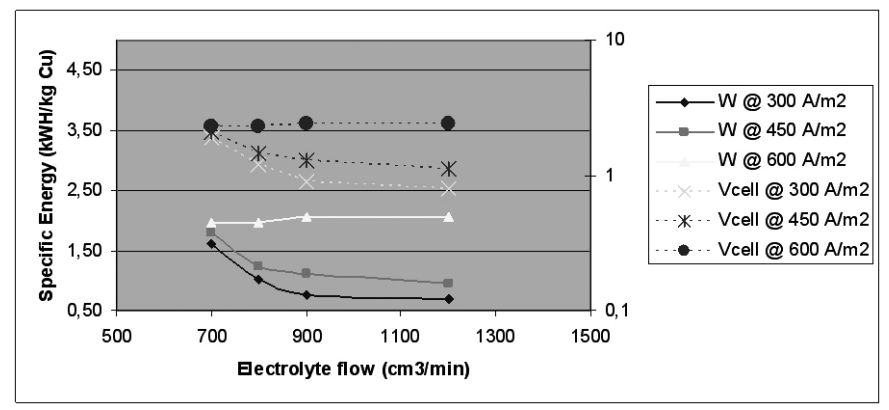

Figure 3.2.- Effect of electrolyte flow on specific energy and $V_{\text {cell }}$ (right $\log y$ axis) at different current densities at $40{ }^{\circ} \mathrm{C}$.

Moreover, in Figure 3.2 it is seen that at $600 \mathrm{~A} / \mathrm{m}^{2}$ the specific energy $(W)$ is practically constant at different electrolyte flows, because for this system $V_{\text {cell }}$ and the deposited copper are constant too (see Equation (3)). On the other hand, at 300 and $450 \mathrm{~A} / \mathrm{m}^{2}$ the value of $W$ decreases when electrolyte flow increases, and this effect is directly proportional to the $V_{\text {cell }}$ decrease described above, because $\eta_{a}$ and $\eta_{c}$ in Equation (2), particularly $\eta_{D}$ of each one, Equation (7), decreases because the concentration gradient and $\delta$ at the electrodes also decrease, and therefore $J_{D}$ is favored (see Equation (6)).

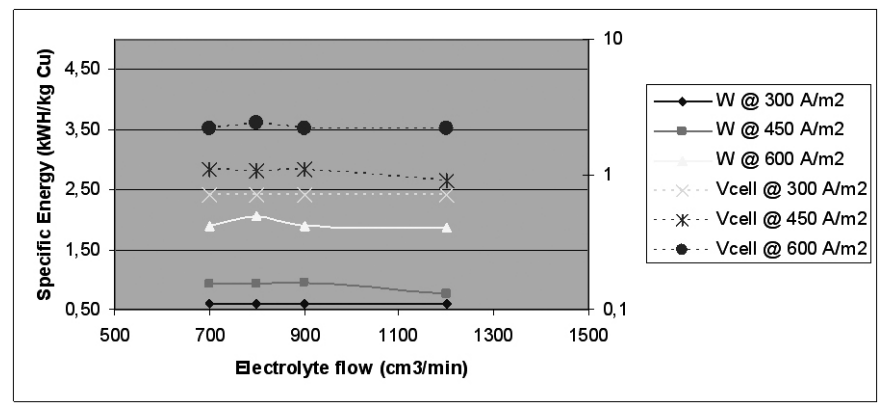

Figure 3.3.- Effect of electrolyte flow on specific energy and $V_{\text {cell }}$ (right $\log y$ axis) at different current densities at $50{ }^{\circ} \mathrm{C}$. 


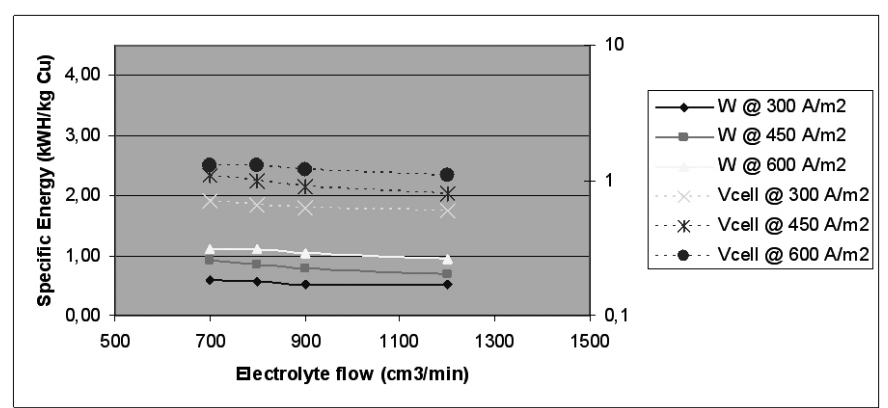

Figure 3.4.- Effect of electrolyte flow on specific energy and $V_{\text {cell }}$ (right $\log y$ axis) at different current densities at $60^{\circ} \mathrm{C}$.

Figures 3.3 and 3.4 show that specific energy and $V_{\text {cell }}$ show a slight decrease with respect to the result of Figure 3.2 at $40{ }^{\circ} \mathrm{C}$, and at higher temperature, particularly at $60{ }^{\circ} \mathrm{C}$ as shown in Figure 3.4, produced the lowest specific energy and cell potential values of all the current densities tested.

Effect of Temperature:

When the work was done at constant electrolyte flow and the temperature increase, a decrease of the cell potential is seen that increases as the flow decreases, showing that as the forced convection conditions in the proximity of the membrane improve, polarization due to concentration close to it is minimized, thereby decreasing the cell's energy expenditure.

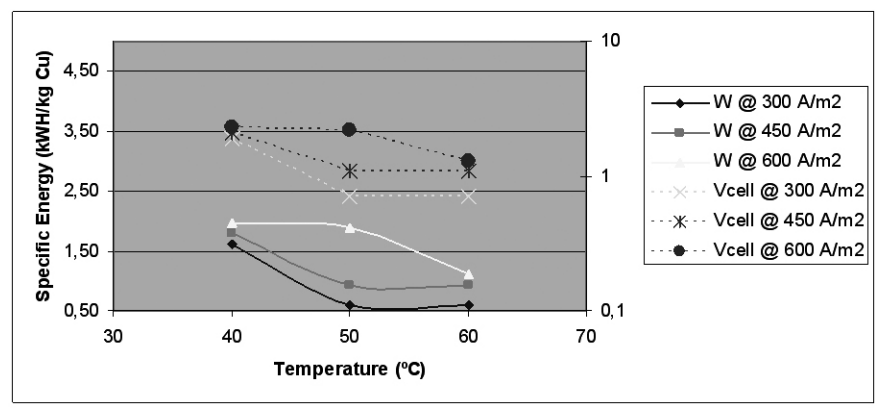

Figure 3.5.- Effect of temperature on specific energy and $V_{\text {cell }}$ (right $\log y$ axis) at different current densities at $700 \mathrm{~cm}^{3} / \mathrm{min}$.

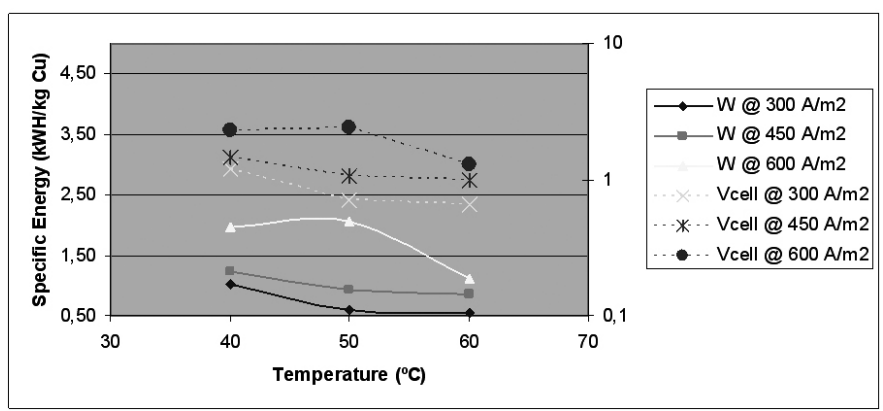

Figure 3.6.- Effect of temperature on specific energy and $V_{\text {cell }}$ (right $\log y$ axis) at different current densities at $800 \mathrm{~cm}^{3} / \mathrm{min}$.

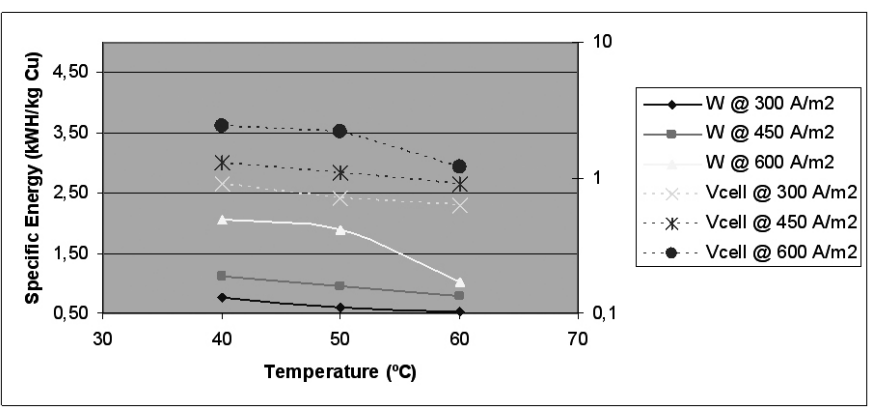

Figure 3.7.- Effect of temperature on specific energy and $V_{\text {cell }}$ (right $\log y$ axis) at different current densities at $900 \mathrm{~cm}^{3} / \mathrm{min}$.

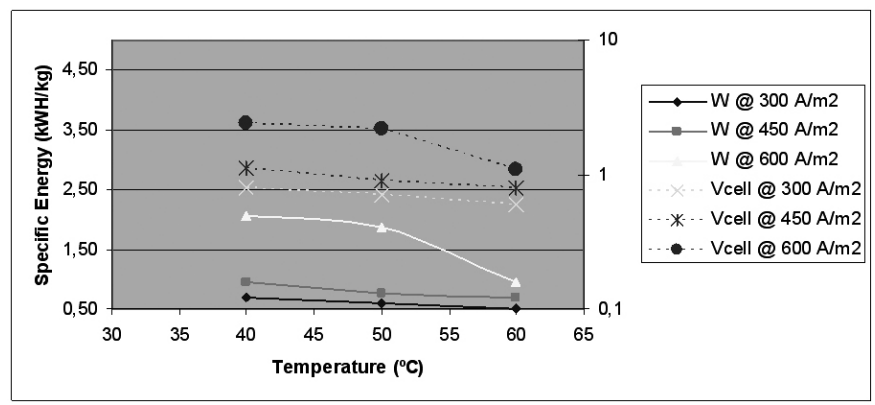

Figure 3.8.- Effect of temperature on specific energy and $V_{\text {cell }}$ (right $\log y$ axis) at different current densities at $1,200 \mathrm{~cm}^{3} / \mathrm{min}$.

Effect of current density:

As expected, an increase in current density implies an increase of the system's cell potential (see Equation 2), but this increase is less significant at an electrolyte temperature of $60{ }^{\circ} \mathrm{C}$ at all electrolyte flows, and particularly at $1,200 \mathrm{~cm}^{3} / \mathrm{min} V_{\text {cell }}$ is minimum (see Figure 3.12) compared to the results shown in Figures 3.9 to 3.11.

This behavior is associated with the fact that at high temperatures and high flows mass transport by diffusion and convection improves with respect to mass transport associated with migration, but it should not be so important because it is in the presence of acid support electrolytes in both the catholyte and the anolyte. Obviously, this behavior must reach an extreme characterized by the limiting diffusion current at each temperature and the electrolyte flow in particular.

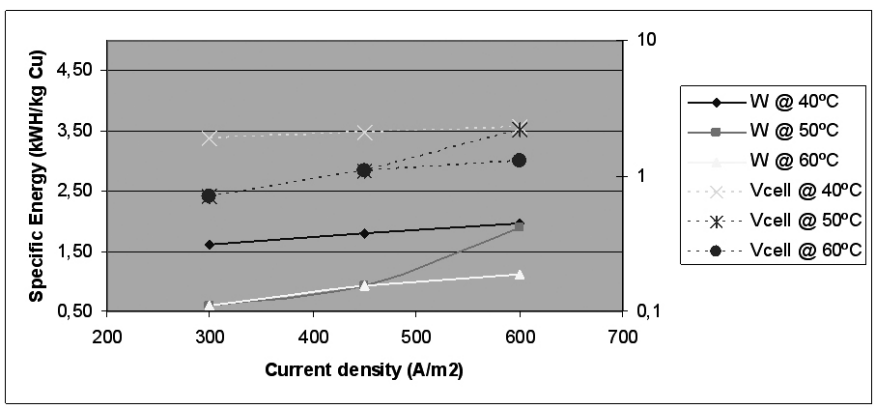

Figure 3.9.- Effect of current density on specific energy and $V_{\text {cell }}$ (right log $y$ axis) at different temperatures at $700 \mathrm{~cm}^{3} / \mathrm{min}$. 


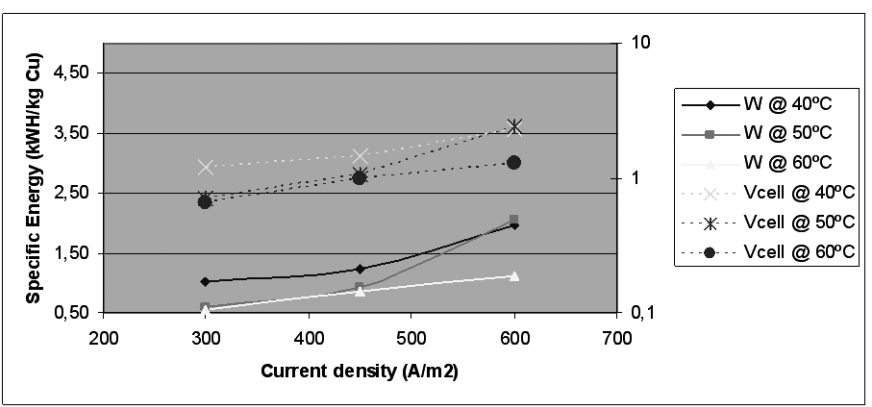

Figure 3.10.- Effect of current density on specific energy and $V_{\text {cell }}$ (right $\log y$ axis) at different temperatures at $800 \mathrm{~cm}^{3} / \mathrm{min}$.

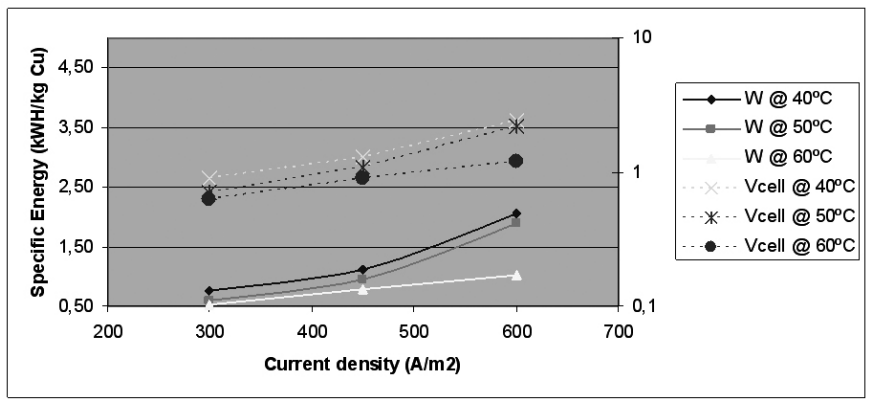

Figure 3.11.- Effect of current density on specific energy and $V_{\text {cell }}$ (right $\log y$ axis) at different temperatures at $900 \mathrm{~cm}^{3} / \mathrm{min}$.

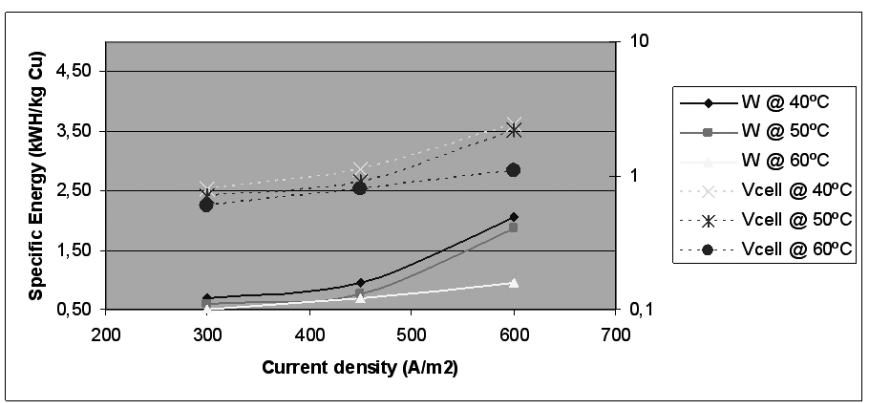

Figure 3.12.- Effect of current density on specific energy and $V_{\text {cell }}$ (right $\log y$ axis) at different temperatures at $1,200 \mathrm{~cm}^{3} / \mathrm{min}$.

The average faradic cathodic efficiency for all the tests was $98.68 \%$, i.e., no change was detected in the current efficiency under all the conditions tested.

\section{CONCLUSIONS}

Using reactive electrodialysis, cell potential and specific energy are decreased with respect to the traditional copper electrowinning system, with a maximum six-fold difference between both processes.

In all the tests the average current efficiency was $98.68 \%$, i.e., no change was detected in the current efficiency under all the conditions tested. The parameters studied here confirm an important aspect of this study is that related to operational flow, which causes great expectation because if work can be done at greater flows, higher limiting currents would be obtained as a consequence of a higher current density, leading to the same copper production with a much smaller infrastructure, high current efficiency, and low specific energy.

\section{ACKNOWLEDGEMENTS}

The authors thank Refinería Electrolítica de Ventanas of CODELCO Chile (Corporation Nacional del Cobre de Chile), and acknowledge the support of the Comisión Nacional de Investigación Científica y Tecnológica under FONDEF project D97I2035.

\section{REFERENCES}

1. J.O'M. Bockris, A.K.N. Reddy, Modern electrochemistry, Plenum Press, New York, (1977).

2. A.K. Biswas, W.G. Davenport, Extractive Metallurgy of Copper, third edition, Pergamon Press, Oxford, (1994).

3. J.M. Casas, F. Alvarez, L. Cifuentes, Chem. Eng. Sc., 55, 6223, (2000).

4. L. Cifuentes, R. Glasner, G. Crisóstomo, J.M. Casas in Procs. Copper 2003, International Conference, J.E. Dutrizac, C.G. Clement eds. Canadian Institute of Mining, Metallurgy and Petroleum, Montreal, 623, (2003).

5. J. Menacho in First Meeting on Minor Element Contaminants in Copper Metallurgy, J. ÁLvarez, R. Padilla, R. Parra, M. Sánchez, F. Vergara, eds., Universidad de Concepción, 169 (2007).

6. J.M. Casas, G. Crisóstomo, L. Cifuentes, Hydrometallurgy, 80, 4, 254, (2005).

7. L. Cifuentes, G. Crisóstomo, J.P. Ibáñez, J.M. Casas, F. Álvarez, G. Cifuentes, J. of Membrane Sc., 207, 1, (2002).

8. L. Cifuentes, R. Glasner, J.M. Casas, Chem. Eng. Sci., 59, 5, 1087, (2004).

9. L. Cifuentes, C. Mondaca, J.M. Casas, Minerals Engineering, 17, 803, (2004).

10. L. Cifuentes, R. Ortiz, J.M. Casas, AIChE J. 51, 8, 2273, (2005).

11. L. Cifuentes, J. Simpson, Chem. Eng. Sci., 60, 17, 4915, (2005).

12. L. Cifuentes, J.M. Castro, J.M. Casas, J. Simpson, Applied Math. Available On Line, (2006).

13. L. Cifuentes, J.M. Casas, J. Simpson, Chem. Eng. Research and Design. 84, A10, 965, (2006).

14. D.C. Price, W.G. Davenport, Metallurgical Transactions B, 12B, 639, (1981).

15. Y. Lorrain, G. Pourcelly, C. Gavach, J. Membrane Sci. 110, 181, (1996).

16. Y. Lorrain, G. Pourcelly, C. Gavach, Desalination, 109, 231, (1997).

17. K. Lott, B. Ghosh, J. Ritchiez, Electrochemical and Solid-State Letters, 8, A513, (2005).

18. J. Newman in Advances in Electrochemistry and Electrochemical Engineering, C. W. Tobias ed., New York, USA, 87, (1967).

19. G. Pourcelly, Y. Lorrain, C. Gavach, Desalination, 109, 231, (1997). 